\title{
Tracking the Gendered Life Courses of Care Leavers in 19th-Century Britain
}

\author{
Pamela Cox University of Essex, UK \\ pamcox@essex.ac.uk \\ Heather Shore Leeds Beckett University, UK \\ Zoe Alker University of Liverpool, UK \\ Barry Godfrey University of Liverpool, UK
}

(Received February $2017 \quad$ Revised June 2017) $\quad$ http://dx.doi.org/10.14301/Ilcs.v9i1.457

\begin{abstract}
The adult outcomes of children raised in care are a matter of much concern in Britain today. Care leavers account for a quarter of the adult prison population, a tenth of the young homeless population, and over two thirds of sex workers (Centre for Social Justice, 2015: 4). This article argues that, by contrast, the first generation of boys and girls passing through the early care system were more likely to have experienced a modest improvement in their life chances. It explores three key questions. First, what mechanisms shaped adult outcomes of care in the past? Second, did these vary by gender? Third, what might life course approaches to these issues gain from engaging both with historical- and gender-inflected analysis? The article draws on our wider analysis of the life courses and life chances of 400 adults who passed through the early youth justice and care systems as children in the northwest of England from the 1860 s to the 1920s. These systems were closely interlinked. Within that, the article focuses on the experiences of a subgroup sent to a more care-oriented institution. It compares their collective outcomes with those of the wider group and within-group by gender. It offers a selection of case studies of women's lives before and after care to highlight the value of, and challenges involved in, undertaking gender analysis in life course research of this kind.
\end{abstract}

\section{Key words}

Adult outcomes of care; life course; gender; child removal

\section{Funding}

This article is based on research funded by the Leverhulme Trust.

\section{Introduction and context}

Over the course of the 19th and early 20th centuries, over half a million children passed through institutional care in Britain. To date, no study has attempted to assess the adult outcomes for those involved. Until recently, such an approach was practically impossible, given the difficulties of tracing the trajectories of individuals born in that period, and especially given that the vast majority were drawn from socially marginal but also mobile households. In recent decades, however, the largescale digitisation of historical sources has opened up new research methodologies that can generate 
new kinds of data to answer new kinds of research questions. Crime historians have been at the forefront of both digitisation and life course approaches in Britain (for overview, see Hitchcock, 2013; Godfrey, 2016). Historical research into the development, delivery and impacts of the care system has also been extremely insightful (Hendrick, 1994; Murdoch, 2006) but has not, thus far, made extensive use of these new approaches.

This article draws on a wider project investigating the impact of Britain's early statesponsored youth justice and care systems across the life course. These two systems were closely interlinked in the 19th and early 20th centuries, indeed they were imagined by many reformers at the time to be part of a necessarily unified response to the interconnected challenges of child poverty, child neglect and child crime. One concrete manifestation of these interconnections came in the form of two new training institutions set up for children in the 1850s: industrial and reformatory schools. Our wider study focuses on the experiences of 400 children passing through three of these institutions and one allied independent institution in the northwest of England from the 1850 s to the 1920s (Godfrey, Cox, Shore \& Alker, 2017). This article focuses on the 171 children within our sample who were sent to Stockport Industrial School, a residential training home set up to care for vulnerable children considered at risk of falling into a life of crime ${ }^{1}$. Overviews of these institutions, together with a summary of our method of researching them and their impacts, are set out in more detail below.

Industrial and reformatory schools were just two among a large variety of institutions involved as 'providers' of care to children. The largest provider was the local state through its local iteration of the national poor law system. From the 1830s on, local poor law officials were encouraged by central government - but also by their own rate-payers - to move away from 'outdoor relief' in favour of 'indoor relief' in an effort to curb spiralling relief costs and to break perceived patterns of dependency. In practice, this meant that thereafter, they opted, where possible, to assist pauper families by admitting them to their local workhouse rather than giving them cash or in-kind support and allowing them to remain in their own homes (Crompton, 1997; Crowther, 1983; Humphries, 2013; Murdoch 2006; Sheldon, 2013). Families admitted to the workhouse were routinely separated, with the children sent to separate wards or, as the century progressed, to separate institutions or poor law 'cottage homes'. Some have argued that this orchestrated and widespread 'child removal' was used as a deliberate tactic of governance to 'incentivise' the destitute to change their habits (Doolittle, 2014; Ward, 1990, 2016). Certainly, this practice did a great deal to cement child removal as a troubling policy norm in the early British welfare state. In turn, this is likely to have helped to lay the normative foundations of child removal across British colonies and provided a core model for the later removal of large numbers of indigenous children by settler populations in Australia and Canada (Cuthbert, Spark \& Murphy, 2010; Jacobs, 2009; Swain \& Hillel, 2010). There has been no large-scale study yet completed of the adult outcomes of Britain's workhouse children one of the largest groups to experience institutional care.

More studies have, however, been undertaken around the experiences of another large group of historical 'care leavers': those sent, again on a massive scale, to homes, orphanages and institutions provided by the voluntary sector across this period. Most of that provision was made by faith-based charities, many of who came to view child removal as one of their core activities. From the 1870s on, the scale of this work expanded further as large charities moved to operate on a more corporate footing and on a more national scale. The Church of England's Incorporated Society for Providing Homes for Waifs and Strays, for example, was set up in the 1880s and would go on to house thousands of children in an (inter)national network of institutions and fostering schemes spanning Britain, Australia and Canada. Still operating today as the Children's Society, and still a major care and child service provider, this organisation's archives and personal case files have been used extensively by historians (Cox, 2003; Murdoch, 2006; Sheldon, 2013; Ward, 1990; Soares, 2016). Current studies that cross-reference this archive with others are beginning to address the issue of the adult impacts of care (Skinner, 2016).

Industrial and reformatory schools were set up by statute in the 1850 s and modelled on existing child institutions run within the poor law and the voluntary sector as well as on previous juvenile prison experiments. All were certified, inspected 
and part-funded by the state. However, the majority were managed, staffed and mostly funded by the faith-based voluntary sector. Industrial schools admitted those under the age of 14 found guilty of committing an offence or judged to be in need of protection. Reformatories admitted offenders up to the age of 16 . They offered basic education and training in a trade and most offered post-custodial supervised employment on release. The two institutions were amalgamated to form 'approved schools' in 1933. Thereafter, and notably with the expansion of the welfare state after 1945, they were much more firmly associated with the justice system rather than the care system which, in turn, then expanded its own institutional provision. Other historical accounts of industrial and reformatory schools have examined their early influences and formation (Stack, 1994; Shore, 1999; Gear, 1999), later reform (Carlebach, 1970; Bailey, 1987) and experiences of staff and young inmates (Cox, 2003; Sheldon, 2013). None, to date, have used life course methods or conducted a systematic assessment of adult outcomes.

\section{Historical life course methodology and sample}

This article analyses the adult outcomes of 171 children sent to Stockport Industrial School (SIS) in the northwest of England. These individuals were randomly selected from entries within SIS admissions registers across the two time spans used across our wider study: (i) 1855-1870, (ii) 18901927. We chose 1855 as a start date to capture some of those sent to a state-certified reformatory during their first year of operation. We chose 1927 as an end date to capture some of those sent to a state-certified reformatory or industrial school in the year that the Home Office recommended that these two institutions should be amalgamated thus effectively ending this first phase of their history. Our core sample is therefore drawn from across the first generations of children to pass through these new youth justice and care institutions.

The sample is predominantly male: 151 boys and 20 girls. This is broadly reflective of gender ratios within admissions to all industrial and reformatory schools across the period concerned and, indeed, of all court proceedings involving juveniles across the same period, where gender is documented (Cox, 2003). By contrast, women made up a larger proportion of adults appearing in court and of those sent to prison. One recent historical study of adult criminal life courses in the same region covered by our analysis was based on a sample made up of $82 \%$ men and 18\% women (Godfrey et al., 2007).

Girls routinely accounted for between $5 \%$ and $10 \%$ of both court proceedings and these institutional admissions, as the figures below illustrate.

Aside from the fact that they were sent in low numbers into this form of institutional care, there are further challenges in studying the adult outcomes of these girls. The similarity of names and ages amongst any female cohort in prison, the workhouse, or a reform institution, means that identifying unique girls and women is difficult. If they married, and adopted their partner's surname, this task is made even harder. The females within our sample were unmarried but became harder to trace into adulthood as they formed relationships with men and, in many cases, went on to marry. Only now is recent historical work beginning to address the gender gap within wider historical life course studies (Williams, 2014; Williams \& Godfrey, 2015). However, our sample of SIS children remains predominantly male, with females making up approximately $6 \%$ of the sample.

Aside from the fact that they were sent in low numbers into this form of institutional care, there are further challenges in studying the adult outcomes of these girls. The similarity of names and ages amongst any female cohort in prison, the workhouse, or a reform institution, means that identifying unique girls and women is difficult. If they married, and adopted their partner's surname, this task is made even harder. The females within our sample were unmarried but became harder to trace into adulthood as they formed relationships with men and, in many cases, went on to marry. Only now is recent historical work beginning to address the gender gap within wider historical life course studies (Williams, 2014; Williams \& Godfrey, 2015). However, our sample of SIS children remains predominantly male, with females making up approximately $6 \%$ of the sample.

SIS was certified as an industrial school in 1866, initially for the reception of around 30 children (Tenth Inspectors Report, 1867: 71). By 1872, it housed 107 children (Webster, 1973: 283). Prior to its certification by the Home Office, it had been a ragged school, founded in 1854 and run by the 
Figure 1. Industrial school population by gender (boys, top line; girls, bottom line), 1860-1892

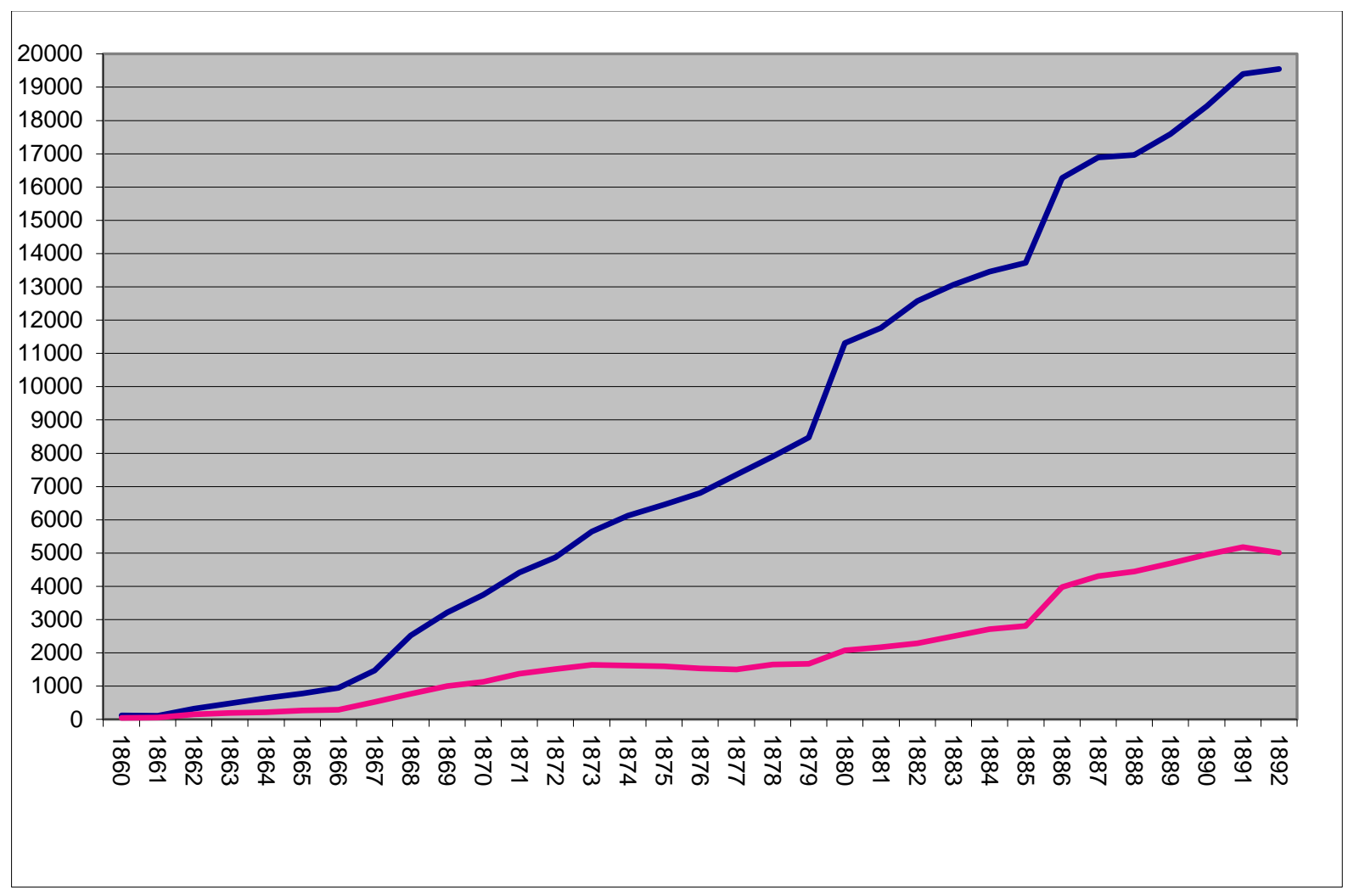

Stockport Sunday School Union, which remained influential in the management of the School. SIS was unusual in that it was one of the few industrial schools to admit both boys and girls, although it housed them in separate wings and put them through distinct training regimes: hatting, printing, cobbling and tailoring for boys and domestic service training for girls. In 1877 , a separate girls' school was opened nearby (Webster, 1973: 308). Our sample also includes a small number of girls sent there. SIS was a facility serving the population of the fast-growing town of Stockport, ten kilometres southeast of Manchester. Of our 171 children, the majority were locally born and had been sent to the institution via local magistrates' courts. The school later admitted a significant number of London-born children sent by the London School Board (and then its successor, the Education Committee of London County Council), which regularly outsourced its care and youth justice cases in this way. Stockport was a textile town with several large cotton mills and many businesses linked to the textile and garment industries as well as to the distribution and transport industries. Between 1860 and 1920, its population grew rapidly and, like many areas in this region, this included a substantial Irish Catholic minority. Our sample is, however, primarily drawn from white, working-class Protestant families - and, more particularly, from non-conformist Protestant communities, namely those with links to Methodism. Children from Catholic or Jewish families appearing before Stockport's magistrates would have been sent to alternative faith-based institutions in Manchester or elsewhere.

Children were typically sent to SIS (and other industrial schools) until they were 16 years old, regardless of the reason for, or their age at, admission. This meant that they spent long periods in care. Those over the age of 14 could be released 'on licence' from the institution itself and found work with a local employer. SIS staff would maintain regular contact during this time with the young person concerned and their employer. This contact took the form of personal letters and visits and, significantly, was frequently maintained by mutual agreement for many years after the end of the licence period and formal exit from care.

Our study maps adult outcomes of care at the individual level through the creation of personal life grids populated with details including: residential 
address, employment, household composition, marital status, parental status and military service; any alleged offences, convictions and further engagement with police or welfare authorities; and any personal materials surviving in other sources. These details have been assembled through the systematic and cross-referenced search of available digitised and institutional records. Adult outcomes of care have then been analysed at the cohort level using multivariate analysis to identify key variables driving 'positive' and 'negative' adult outcomes (for full discussion, see Godfrey et al., 2017). These variables were derived from research designs developed within cognate studies in life course criminology, life course crime history and desistance studies (Sampson \& Laub, 2003, 2006; Bijleveld and Wijkman, 2009; Godfrey, Cox \& Farrall, 2007, 2010).

Our unique evidence base allowed us to identify patterns of (re)offending on release and subsequent experiences of the criminal justice system and other interventions. We use these findings to explore the possibilities of applying adapted predictive risk methods within historical life course research and to identify factors beyond institutional corrections that shaped the broader life-chances of our group. For children who were sent to SIS, the majority (89\%) never re-offended after release; a minority (10\%) did re-offend, but only one person committed more than five offences.

In addition to re-offending rates, we also examined the experiences that children from SIS had whilst on work-placement and on licence; whether the children went on to marry and/or to have children as adults; whether they secured employment; whether they moved around the country or stayed in one place for most of their lives. The factors we identified as significant chime with those derived from other studies of contemporary care outcomes. In particular, these variables allow us to ask questions that are very pertinent to current debates within care provision, notably whether institutional care offers 'protective' or 'harmful' effects and whether it contributes to or reduces 'cumulative disadvantage'. Researchers are divided on this question. Some argue that 'good care' promotes resilience and thereby helps 'looked after children' to 'overcome the odds' created by their difficult early lives (see, for example, Stein, 2005). Others counter that even 'good care' tends to damage future life chances (see, for example, Centre for Social Justice, 2015). The concept of 'cumulative disadvantage', used by Sampson and Laub (1993, 1997) to describe the accumulation of deficits that further decrease the probability of positive life chances for those already on the wrong side of the strain society, is very useful in assessing adult outcomes of historical care (Godfrey et al., 2017, chapter 1). The remainder of this article compares the collective outcomes of our SIS subgroup $(n=171)$ with those of our full sample $(n=400)$. It also undertakes an exploratory 'within-subgroup' comparison by gender in order to investigate and ameliorate the relative neglect of gender differences in within life course studies of this kind.

\section{Findings: adult outcomes of care in}

\section{9th- and early 20th-century Stockport}

Of the 171 children in our sample passing through SIS from the 1850s to the 1920s, the vast majority went on to lead what can be described as 'regular' working-class lives: they found work, they married, they lived in households, they earned enough to share rented accommodation in local neighbourhoods, they avoided significant later involvement with the police or welfare authorities. In stark contrast to care leavers today, few experienced long-term unemployment, homelessness or significant later involvement with criminal justice or welfare systems. For these children, their involvement in what Foucault famously termed the 'great confinement' (1967) was followed by what we might term the 'great reintegration'.

Our evidence suggests that very few of the children in our sample facing early childhood risk went on to become 'life course persistent offenders'. This important finding is in line with the conclusions reached by Sampson and Laub over several significant studies (1993, 2003, 2006). Our own study has been conducted with a different population over a different time period but reaches the same broad conclusion as Sampson and Laub. Only 18 of the 171 SIS individuals went on to offend after their release - in all cases committing only minor offences. As stated earlier, remarkably, only one young man went on to become a persistent offender (see table 1).

It is important to note here that only $25 \%$ of these children had offended at all prior to their 
admission to the institution and that their offences were trivial involving minor theft, public order and regulatory offences, notably around street play. The remaining $75 \%$ had been sent to SIS for truancy $(19 \%)$, vagrancy $(30 \%)$, having inadequate parents (12\%), being out of control $(10 \%)$ or having bad associations (3\%). Together with the Indefatigable training ship, which also admitted boys in need rather than young offenders, SIS - not surprisingly produced the best post-release offending rates within our group of four institutions. Only one of the 50 Indefatigable boys in our sample is known to have offended post-release. Of the two reformatories in our study, Bradwall produced much more positive adult outcomes of care than the Akbar training ship.

One third of the 142 Bradwall boys in our sample were involved in post-release offending (compared with just over one tenth of Stockport children). Again, most of these offences were minor and only four individuals went on to commit more than five offences over their life course. The Akbar produced the highest post-release offending rates involving nearly half $(47 \%)$ of the 36 boys in the sample although only three $(8 \%)$ committed more than five recorded crimes over their life course. It is significant that the Akbar was viewed locally as a reformatory for more 'hardened' young offenders believed able to bear the notoriously harsh naval discipline that was common to many of Britain's juvenile training ships. In terms of wider life chances within these adult outcomes, combined analysis of data taken from our full sample's license records and census entries shows that most entered three broad types of employment: 'industrial', 'agricultural', 'seafaring'. Within these, boys took jobs as, for example, porters, agricultural labourers, wireless operators, hatters, printers, shoemakers, railway workers, soldiers and sailors, or were self-employed across a variety of trades. Girls typically worked in textile mills and related trades, in domestic service or retail. These jobs were part of the occupational fabric of everyday working-class life in 19th- and 20th-century Britain and their availability played a crucial part in shaping 'successful' adult care outcomes. For example, Amanda B was born in Manchester in 1866 and then moved with her family to Stockport. She was admitted to SIS in 1874 at the age of eight for 'being beyond control'. Her father had recently died and her mother had apparently been admitted to Macclesfield lunatic asylum (although we found no record of her there), leaving Amanda and her five siblings in the care of her grandmother, then in her early 70s. She had been brought to court by her teenage siblings. Amanda was described as having been 'very troublesome' in the past and as 'having taken to pilfering and staying away from home'. On admission to SIS, she was noted to be "healthy, clean and well-clothed'. She was discharged from SIS in 1882 at the age of 15 or 16 and did not appear thereafter in local criminal registers or newspaper crime reports across the period covered by our study. The 1901 census lists her, at the age of 34 , as a single woman working as a 'general domestic servant'. She was living in Stockport with a widowed grocer, and his two sons. Ten years on, 44-year-old Amanda was listed as a grocer in her own right in a different premises and living in a multi-generational household comprising her sister (50), brother-in-law (54), niece (21), nephew (23), and great-niece (2). All the adults, aside from Amanda, were working in the hat trade. She died in Stockport at the age of 74 in 1941, having progressed from domestic servant to a small-trader. We suggest this stabilised her prospects and those of her extended family.

Unlike Amanda, most women did not manage to escape a low position in the labour force. At the turn of the 20th century, over half of all British workers worked in partly skilled or unskilled jobs and less than a third worked in skilled occupations (Crafts and Mills, 1994: 176). Military service also played a significant part in the post-release lives of many of the boys sent industrial and reformatory schools as a whole. Thirty (17\%) of our SIS sample entered the army or navy, most of them during the First World War (Alker \& Godfrey, 2014). 
Table 1: Reconviction figures by institution

\begin{tabular}{|l|r|r|r|r|r|r|r|r|}
\hline Institution & \multicolumn{2}{|c|}{ Non-offenders } & \multicolumn{2}{|r|}{ Occasional } & \multicolumn{2}{|r|}{ Persistent } & \multicolumn{2}{|r|}{ Total: } \\
\hline & No. & $\%$ & No & $\%$ & No & $\%$ & No & $\%$ \\
\hline Akbar & 19 & 53 & 14 & 39 & 3 & 8 & 36 & 100 \\
\hline Bradwall & 95 & 67 & 43 & 30 & 4 & 3 & 142 & 100 \\
\hline Indefatigable & 49 & 98 & 1 & 2 & 0 & 0 & 50 & 100 \\
\hline Stockport & 154 & 89 & 17 & 10 & 1 & 1 & 172 & 100 \\
\cline { 2 - 9 } Totals & 317 & 79 & 75 & 19 & 8 & 2 & 400 & 100 \\
\hline
\end{tabular}

Overall, then, children sent to SIS between the 1850 s and the 1920 s did not experience cumulative disadvantage - as defined by Sampson and Laub as a result of their period in care. If SIS 'worked' as an institution, it worked because of three particular mechanisms operating in a particular social and economic context (Pawson \& Tilley, 1994, 1997; Godfrey et al., 2017). First, most care leavers were placed in what would today be termed 'through the gate' jobs - meaning that they passed straight from the institution into supervised employment within a buoyant local labour market. Second, that supervision involved an important affective dimension. SIS - like almost all others institutions of this type during this period - operated an after-care system in which staff maintained contact with young people after they left. In many cases, this contact could last for decades, with both parties exchanging regular letters, sometimes across continents. Some Stockport leavers returned to visit the institution as adults. In our wider study, we argue that these ongoing relationships are likely to have contributed to these broadly positive outcomes. While they can never be measured in the same way as a documented marriage, they nevertheless seem to have played a key part for many. Third, those leaving SIS were able to find affordable housing relatively close to their workplaces and often within, or close to, familiar communities. Their communities were often poor with few amenities and their rented houses often over-crowded with few facilities. However, they provided a social and economic network and, just as important, an affective relational network that together, promoted social inclusion rather than exclusion.
We are also very mindful, however, of more negative factors that cannot be easily measured or even documented or articulated. Child removal may have offered some clear protective effects, as indicated above. However, it is also likely to have generated harmful effects that were not limited to measurable cumulative disadvantage. A further mechanism central to the 'success' of SIS - in terms of preventing offending and giving young people time to acquire marketable skills - was the long 'sentence' served by the children sent there. This meant that they were effectively cut off from their families for up to several years - with untold effects. It is very possible that those care leavers who went on to lead 'regular' working-class lives also went on to carry significant personal trauma as well as to have transmitted this in some respect to their own children.

For example, Margaret L's case could be presented as an example of the intergenerational transmission of delinquency or, alternatively, an example of how women like her managed marginality and negotiated stigma. Margaret was born in Stockport in 1860 to a single mother described as a 'greengrocer' in 1861 and later as a 'hawker of fruit'. A decade on, she had moved with her mother and two year-old brother to a lodging house. Her father is said to have died in 1870 although it is not clear who he was or where he lived. In April 1872, at the age of 12, Margaret was convicted of theft at Stockport magistrates' court, seemingly part of a pattern of behaviour. The court noted that she was 'in the habit of stealing from her mother and her schoolmates', and they sent her to the reformatory for five years. As she was under the age of 14, Margaret served her sentence in 
Stockport Industrial School. By 1881, now 20, Margaret was employed as a live-in domestic servant to a tailor, his wife and young family in Blackburn, a town 30 miles away. By 1891, aged 30, she had moved back to Stockport, and was working as a charwoman and living with her own two children, Sarah (aged 15) and Herbert (aged 6) in a two-room house.

If these ages are correct, this suggests that Margaret had given birth to Sarah when she herself was 15 or 16 and that she had found a way to maintain her young daughter whilst working in domestic service. Margaret is listed as married in 1891 and 1901 but we have found no evidence of her marriage and no indications where her purported husband lived. In 1901, she was still living with her daughter, then aged 25 and also an unmarried charwoman, and her son, then aged 17 and working as a casual labourer and messenger. Her son, Herbert, had just been released from his own four-year sentence in SIS where he had been sent having 'been found begging'. During his court proceedings, his mother was described as 'a charwoman fond of drink and a loose character' - a common euphemism for a professional or amateur sex worker. His father was named as Walter L, a local man, who worked as a caster (likely within a local metal works), and was described as 'a decent man' who had 'lived separate' from Margaret for 'several years'. Their shared surname may indicate an incestuous or at least a close familial connection between his parents. Herbert was discharged from SIS in 1899 at the age of 16. Unusually, he was 'returned to mother' as he was 'too small to place in a situation'. This may possibly indicate that Herbert had grown up with some kind of physical disability or congenital condition. However, he was still able to work, and doubtless, had to in order to survive. The 1901 census lists him, as outlined above, living with his mother and his sister and working as a casual labourer and messenger. The following year, Margaret died at the age of 48 .

The practice of child removal was established as a new norm in 19th-century social policy but this did not mean that its effects were normalised among those directly experiencing it. Child separation could be an emotionally brutal business, the 'success' of which was exacted at a high emotional price, even where it was carried out humanely and with the best of intentions. Stockport Industrial School was not among the many institutions formally investigated for child cruelty in the period covered by our study. This does not mean, however, that the children in its care did not experience that care as abusive (Bingham,Delap, Jackson \& Settle, 2016.

\section{Gender and historical life course methodology}

Our exploratory 'within-subgroup' comparison by gender is undertaken here as a constructive effort to address the neglect of gender issues within the broader field of life course criminology (one of our main points of references in our larger study). Justice systems around the world deal primarily with men. Longitudinal and life course studies deal primarily with large data sets. As a minority within justice systems, women are rarely present in large enough numbers to be included in their analysis. Our own broader study is no exception: $96 \%$ of our sample is male. However, the result of this is that life course studies have had little to say about gender differences and how these might play out within pathways into and out of crime or cumulative disadvantage. Life course desistance studies have argued, for example, that marriage, employment and social networks 'work' for men (Sampson \& Laub, 1993, 1997; Maruna, 2001; Godfrey et al., 2007, 2010; Farrall \& Calverley, 2006). But do they 'work' for women in the same way?

Alice $C$ was born in 1865. At the age of eight, she was sent by local magistrates to Stockport Industrial School for theft. Her previous character was noted in court to be 'very bad' and her mother, Martha C, a Stockport factory worker, was described as 'well known to the police'. Alice was discharged from SIS in 1882 at the age of 16 . We have no details of her address or occupation at this point. However, the 1891 census shows 26 year old Alice living back with her parents, her two teenage sisters, and her own eight-month-old daughter. Sharing the house with them was a lodger, presumably to help out with the rent. The whole household was employed in the local cotton mill. Later that year, Alice married the lodger, who may or may not have been the father of her baby. Ten years on, they were still married, living nearby with three more children. Alice, now 36 , is not listed as being in paid work and is, we imagine, occupied as the mother of young children. Her husband had moved from the cotton mill to a printing firm where he was employed as a carter (or 
delivery driver). Alice died in Stockport in 1920 at the age of 55. In Alice's case, the marriage is likely to have helped her to secure economic security after a precarious start in life. However, her experience needs to be considered alongside that of Amanda B (outlined above), who achieved that security as a single, but working, woman. Their experiences clearly speak to the need for more historical life course work of this kind.

Bersani, Laub and Nieuwbeerta (2009:3) note that evidence from the past two decades of life course criminological research "consistently demonstrates that salient life events-in particular, marriage-are associated with a reduction of offending across the life course" but that this evidence is largely drawn from "male samples in the United States". As a result, they argue that "questions regarding the universal effect of these relationships remain" and that "[s]pecifically, research is needed to assess whether the desistance effect of life events like marriage varies by gender and/or socio-historical context in countries other than the U.S.". Their article addresses these gaps by exploring the relationship between marriage and criminal offending using data from the Criminal Career and Life Course Study, a dataset covering a significant portion of the life courses of c.5,000 men and women convicted in the Netherlands in 1977. They found "consistent support for the idea that marriage reduces offending across gender and socio-historical context" (ibid).

Studies like these are extending welcome new ground in life course studies (Uggen \& Kruttschnitt, 1998; Giordano, Cernkovich \& Rudolph, 2002; Giordano, Deines \& Cernkovich 2006; Barr, 2016) but they also raise further questions about the definition and measurement of universal effects. Marriage, parenting, work and relationships are cultural practices and their meanings change over time and space. Most leading life course criminological studies analyse large cohorts of men born in the global north in the second half of the 20th century (for two classic US and British examples, see Glueck \& Glueck, 1968; Farrington, Piquero \& Jennings, 2013). Their experience of these practices is likely to be quite different in many respects from that of those born a century or more earlier or those born in other parts of the world. It is also likely to be quite different from that of their wives, mothers and grandmothers. Elements of these differences are highlighted in a further Dutch study of the effects of family formation on criminal careers for 540 high-risk men and women that identifies important gender differences: marriage and parenthood (particularly of a first child) promoted desistance for men, yet "female offending patterns were not significantly influenced by marital status or motherhood" (ZoutewelleTerovan, van der Geest, Liefbroer \& Bijleveld, 2014:1209). We seek to apply insights from new studies like this within our exploratory analysis of gender differences in adult outcomes of the early British youth justice and care systems.

That said, undertaking this analysis is challenging within historical life course studies. As outlined above, the numbers of women involved are small and many of them change their names on marriage. This difficulty is further compounded by the fact that British censuses were only conducted every ten years and because undertaking digital research of British public birth, marriage and death data incurs significant financial costs as it is reliant on private commercialised online archive platforms (such as www.findmypast.co.uk and www.ancestry.co.uk).

Overall, how did the girls sent to SIS fare as adult women? They were sent in much smaller numbers yet their life courses are just as deserving of our attention - both in their own right and because they offer insights into how we might adapt desistence frameworks to analyse the adult outcomes of thousands more girls (and boys) placed institutional care in this period, not because they were offenders but because they were destitute or judged to be in need of protection. Of the 20 girls within our SIS sample, the majority went on, like the boys in our sample, to live regular working-class lives. For women in this period, this typically involved working in an unskilled job until they married and then, if they went on to have children, combining unpaid care work with informal casual work, such as charing, cleaning, child-minding or taking in laundry or piecework (Holloway, 2007; Todd, 2005). For working-class women, marriage and motherhood was as much a form of work as a set of affective relationships. Their route out of cumulative disadvantage was typically a more relational, rather than a more individual, one. It was based on their dependence on others and interdependence with others, rather than their independence from others (Mackenzie \& Stoljar, 2000). This is not to suggest that women actively 
chose this relational route in the way that a man in this period might more actively choose one pathway over another: on the contrary, workingclass women had far fewer options over, and exercised far less autonomy within, their life course than working-class men. The range of full-time jobs open to them, for example, was much narrower and they were often expected to give up those jobs when they married. Their ability to live independently was greatly curtailed in a period when significant gender pay gaps were customary across all employment sectors and when they faced challenges renting or buying their own property.

In a rare life course study of more-recent care outcomes in Britain, Horrocks (2002) compares maturational accounts and socio-historical accounts of journeys in and out of care. She notes that the former tend to prioritise the concept of 'independence' as a desired outcome but argues that this "carries with it a host of expectations: autonomy, self-reliance and obligation" (2002: 325). Horrocks is concerned with the use of age rather than gender as a variable in these kinds studies and with the fact that children from different sociocultural backgrounds will have grown up with different definitions of 'independence' - and also notes that, as stressed by socio-historical accounts of care journeys, perceptions of independence change over time. However, her argument can be extended to the analysis of gender differences within adult care outcomes. It could be argued that we all live what can be described as 'relational life courses' but that women in the past tended to experience this more intensely than men because they had fewer chances to opt out and/or because they derived more emotional and material benefit from their relationships.

The life courses of the three women detailed here present very different pathways to adult outcomes, all of which contain positive elements. At one level, their shared beginnings produced divergent lives (to paraphrase Sampson \& Laub, $1993,2003,2006)$. At another, however, the degree of divergence between them is slight: all of the women found local work and local housing, all maintained family lives and relationships and none seem to have had any further personal involvement in the criminal justice system. Amanda B remained single, went on to run a business and to share a household with her sister and brother-in-law. Margaret $L$ also remained single but raised two children and maintained a precarious but networked existence for her family through charing and other forms of casual work. That work may have involved casual sex work but, if so, did not bring her into contact with the criminal justice system, although may have contributed to her son's admission to SIS. Alice $\mathrm{C}$ followed a more conventional route - first returning to live with her extended family whilst working at a local mill, then marrying and raising a family of her own supported by her husband's salary.

Their life courses highlight many unanswered questions around the gendered dynamics of desistance and re-integration. They show that life course approaches to adult outcomes of care and correction stand to gain a great deal by further engaging with socio-historical and gender analysis. In particular, they suggest that more research is needed into the effects of marriage, work, parenthood and relationships for women in the past and that male offenders' experiences of these cultural practices in particular places and at particular points in time should not stand as a universal, gender-neutral, ahistorical norm.

\section{Conclusion}

This article offers one of the first historical accounts of adult outcomes of the early British care system. Based on a wider study of the life courses of a large group of children (mostly boys) passing through new state-sponsored institutions set up in the 1850 s, it finds that - unlike care leavers today - the majority did not experience documented cumulative disadvantage in later life. Focusing within this on 171 children sent to an industrial school in the northwest of England, it suggests that their positive adult outcomes can be explained by post-release work placements within a buoyant local labour market, the lasting impact of affective relationships established through post-release supervisory arrangements and the wider relationships and networks that facilitated their local re-integration (see Godfrey et al., 2017 for full account). However, it argues that these positive adult outcomes came at a price: child removal could be brutal and typically involved long periods of separation of children from families. It may never be possible to document or measure the harmful and traumatic effects of care delivered in this troubling form. The article also offers an exploratory analysis of the gendered dynamics of 
desistence and re-integration within this group of care leavers. It suggests that key experiences across the life course, namely work, marriage, relationships and independence, carry particular meanings for men and women at particular points in time. It concludes that life course studies would benefit from further work of this kind that could offer more nuanced understandings of the different pathways taken by, and open to, socially marginal men and women.

\section{References}

Alker, Z. and Godfrey, B. (2014). War as an opportunity for divergence and desistence from crime, 17501945. In S. Walklate and R. McGarry (Eds.), Criminology and war: Transgressing the borders (pp7794). London: Routledge

Bailey, V. (1987). Delinquency and citizenship: Reclaiming the young offender, 1914-1948. Oxford: Clarendon Press.

Barr, U. (2016). Ontological theory and women's desistance: Is it simply a case of 'growing up'? Howard League Bulletin, 30, Sept 2016.

Bersani, B. E., Laub, J. H. and Nieuwbeerta, P. (2009). Marriage and desistance from crime in the netherlands: Do gender and socio-historical context matter? Journal of Qualitative Criminology, 25(1), 3-24. https://doi.org/10.1007/s10940-008-9056-4

Bijleveld, C. C. J. H., and Wijkman, M. (2009). Intergenerational continuity in convictions: A five-generation study. Criminal Behaviour and Mental Health, 19(2), 142-155. https://doi.org/10.1002/cbm.714

Bingham, A., Delap, L., Jackson, L., and Settle, L. (2016). Historical child sexual abuse in England and Wales: The role of historians. History of Education, 45(4), 411-429.

https://doi.org/10.1080/0046760X.2016.1177122

Carlebach, J. (1970) Caring for children in trouble. London, Routledge \& Kegan Paul

Centre for Social Justice (2015). Finding their feet: equipping care leavers to reach their potential. Report. London: CSJ http://www.centreforsocialjustice.org.uk/core/wpcontent/uploads/2016/08/Finding.pdf

Cox, P. (2003). Gender, justice and welfare: Bad girls in Britain, 1900-1950. Basingstoke: Palgrave.

Crompton, F. (1997). Workhouse children. Stroud: Sutton Publishing.

Crowther, M. A. (1983). The workhouse system: The history of an English social institution. Abingdon: Routledge.

Cuthbert, D., Spark, C., and Murphy, K. (2010). "That was then, but this is now": Historical perspectives on intercountry adoption and domestic child adoption in Australian public policy. Journal of Historical Sociology, 23(3), 427-452. https://doi.org/10.1111/j.1467-6443.2010.01376.x

Doolittle, M. (2014). 'The duty to provide: Fathers, families and the workhouse in England, 1880-1914'. In B. Althammer, A. Gestrich, and J. Grundler, The welfare state and the deviant poor' in Europe, 18701933. Basingstoke: Palgrave Macmillan. https://doi.org/10.1057/9781137333629 4

Farrall, S. and Calverley, A. (2006). Understanding desistance from crime. London: Open University Press. Farrington, D.P., Piquero, A.R., and Jennings, W.G. (2013). Offending from childhood to late middle age: Recent results from the Cambridge study in delinquent development. New York: Springer. https://doi.org/10.1007/978-1-4614-6105-0

Foucault, M. (1967). Madness and civilisation: A history of insanity in the age of reason. (R. Howard, Trans.). London: Tavistock Publications.

Gear, G. C. (1999). 'Industrial schools in England, 1857-1933: Moral hospitals or oppressive institutions?' (Unpublished doctoral thesis). University of London Institute of Education, London.

Giordano, P. C., Cernkovich, S. A., and Rudolph, J. L., (2002). Gender, crime, and desistance: Toward a theory of cognitive transformation. American Journal of Sociology, 107, 990-1064. 
Giordano, P.C., Deines, J. A., and Cernkovich, S. A. (2006). In and out of crime: A life course perspective on girls' delinquency. In K. Heimer and C. Kruttschnitt (Eds.), Gender and crime: Patterns in victimization and offending (pp 17-40). New York, NY: New York University Press.

Glueck, S. and Glueck, E. (1968). Delinquents and non-delinquents in perspective. Boston: Harvard University Press. https://doi.org/10.4159/harvard.9780674188754

Godfrey, B. (2016). Liquid crime history: Digital entrepreneurs and the industrial production of 'ruined lives'. In M. H. Jacobsen and S. Walklate, (Eds.) Liquid criminology: Doing imaginative criminological research. Aldershot: Ashgate.

Godfrey, B., Cox, D., and Farrall, S. (2007). Criminal lives: Family, employment and offending. Oxford: Clarendon Series in Criminology Oxford University Press. https://doi.org/10.1093/acprof:oso/9780199217205.001.0001

Godfrey, B., Cox, D., and Farrall, S., (2010). Serious offenders. Oxford: Clarendon Series in Criminology, Oxford University Press.

Godfrey, B., Cox, P., Shore, H., and Alker, Z. (2017). Young criminal lives: Life courses and life chances after 1850. Oxford: Clarendon Series in Criminology, Oxford University Press (due for publication October 2017).

Hendrick, H. (1994) Child Welfare: England, 1872-1989. London, Routledge

Hitchcock, T. (2013). Confronting the digital, or how academic history writing lost the plot. Cultural and Social History, 10(1), 9-23. https://doi.org/10.2752/147800413X13515292098070

Horrocks, C. (2002). Using life course theory to explore the social and developmental pathways of young people. Journal of Youth Studies, 5(3), 325-336.

Holloway, G. (2007). Women and work in Britain since 1840. London: Routledge.

Humphries, J. (2013). Care and cruelty in the workhouse: Children's experiences of residential poor relief in eighteenth and nineteenth-century England. In N. Goose and K. Honeyman (Eds.), Childhood and child labour in industrial England: Diversity and agency, 1750-1914 (pp. 115-134). Farnham: Ashgate.

Jacobs, M. D. (2009). White mother to a dark race: Settler colonialism, maternalism, and the removal of indigenous children in the American West and Australia, 1880-1940. Nebraska: University of Nebraska Press.

Mackenzie, C. and Stoljar, N. (Eds.) (2000) Relational autonomy: Feminist perspectives on autonomy, agency, and the social self. Oxford: Oxford University Press.

Maruna, S. (2001). Making good: How ex-convicts reform and rebuild their lives. Washington, DC: American Psychological Association Books. https://doi.org/10.1037/10430-000

Murdoch, L. (2006). Imagined orphans: Poor families, child welfare and contested citizenship in London. New Brunswick (NJ): Rutgers University Press.

Pawson, R. and Tilley, N. (1994). What works in evaluation research? British Journal of Criminology, 34(3), 291-306. https://doi.org/10.1093/oxfordjournals.bjc.a048424

Pawson, R. and Tilley, N. (1997). Realistic evaluation. London: Sage.

Sampson, R. J. and Laub, J. H. (1993). Crime in the making: Pathways and turning points through life. Boston: Harvard University Press.

Sampson, R. J. and Laub, J. H. (1997). A life-course theory of cumulative disadvantage and the stability of delinquency. In T. Thornberry, (Ed.) Developmental theories of crime and deviance. Advances in criminological theory (pp. 133-162). Vol. 7. New Brunswick: Transaction Publishers.

Sampson, R. J. and Laub, J. H. (2003). Life-course desisters? Trajectories of crime among delinquent boys followed to age 70. Criminology, 41(3), 555-592. https://doi.org/10.1111/j.17459125.2003.tb00997.x

Sampson, R. J. and Laub, J. H. (2006). Shared beginnings, divergent lives: Delinquent boys to age 70. Boston: Harvard University Press. 
Sheldon, N. (2013). Something in the place of home: Children in institutional care, 1850-1918. In N. Goose and K. Honeyman (Eds.), Childhood and child labour in industrial England: Diversity and agency, 1750-1914 (pp. 255-276). Farnham: Ashgate.

Shore, H. (1999) Artful dodgers: Youth and crime in early nineteenth century London. Woodbridge: Boydell Press

Skinner, A. (2016). 'Cringe or starve': Did the Charity Organisation Society hinder or help families? Unpublished paper presented to symposium on 'Living the Family', University of Leicester, 8 Nov 2016.

Soares, C. (2016). Alternative families: Affective ties, aftercare and children's experiences in The Waifs and Strays Society. Unpublished paper presented to symposium on 'Living the Family', University of Leicester, 8 Nov 2016.

Stack, J.A. (1994) Reformatory and industrial schools and the decline of child imprisonment in mid-Victorian England and Wales. History of Education, 23(1), pp.59-73.

https://doi.org/10.1080/0046760940230104

Stein, M. (2005). Resilience and young people leaving care: Overcoming the odds. York: Joseph Rowntree Foundation.

Swain, S. and Hillel, M. (2010). Child, nation, race and empire: Child rescue discourse, England, Canada and Australia, 1850-1915. Manchester: Manchester University Press.

Tenth report of the inspector appointed, under the provisions of the Act $5 \& 6$ Will. IV. c. 38 , to visit the certified reformatory and industrial schools of Great Britain, 1867, vol. 36.

Todd, S. (2005). Young women, work and family in England 1918-1950. Oxford: Oxford University Press. https://doi.org/10.1093/acprof:oso/9780199282753.001.0001

Uggen, C. and Kruttschnitt, C. (1998). Crime in the breaking: gender differences in desistance. Law and Society Review, 32, 339-366. https://doi.org/10.2307/827766

Ward, H. (1990). The charitable relationship: Parents, children and the Waifs and Strays Society (Unpublished doctoral thesis). University of Bristol, Bristol.

Ward, H. (2016). Outcomes of care in the 19th century: Historical antecedents to contemporary issues. Unpublished paper presented to the 'Trauma, tragedy and triage: Narratives of troubled children and families in late nineteenth century England and Wales' symposium, Oxford Brookes, 12 May 2016.

Webster, D. H. (1973). The ragged school movement and the education of the poor in the nineteenth century (Unpublished doctoral thesis). University of Leicester, Leicester.

Williams, L. (2014). 'At large': women's lives and offending in Victorian Liverpool and London (Unpublished doctoral thesis). University of Liverpool, Liverpool.

Williams, L. and Godfrey, B. (2015). Intergenerational offending in Liverpool and the north-west of England, 1850-1914. The History of the Family, 20(2), 189-203. Special issue: The Family and the History of the Prison. https://doi.org/10.1080/1081602X.2014.990478

Zoutewelle-Terovan, M., van der Geest, V., Liefbroer, A., \& Bijleveld, C. (2014). Criminality and family formation: Effects of marriage and parenthood on criminal behavior for men and women. Crime \& Delinquency, 60(8), 1209-34. https://doi.org/10.1177/0011128712441745 


\section{Endnotes}

1. The other three institutions in our study are as follows: Bradwall reformatory school located near Sandbach in Cheshire; and the Akbar and Indefatigable training ships, both moored on the River Mersey near Liverpool. The Akbar accepted reformatory cases from the 1850 s and later operated as a land-based school nearby under the new name Heswall Nautical School. The Indefatigable was established as an independent training ship in the 1860s for destitute and orphan boys and was funded by voluntary subscription. Unlike the other three institutions in our study, the Indefatigable was never certified by the state as an industrial or reformatory school.

2. Figures taken from annually published criminal statistics, 1856-1914. 